\title{
COMPARISON OF BACTERIAL AND ARCHAEAL COMMUNITIES FROM DIFFERENT HABITATS OF THE HYPOGENIC MOLNÁR JÁNOS CAVE OF THE BUDA THERMAL KARST SYSTEM (HUNGARY)
}

\author{
Dóra Anda¹, Gergely Krett ${ }^{1}$, Judit Makk ${ }^{1}$ Károly Márialigeti ${ }^{1}$, Judit Mádl-Szőnyi², \\ and Andrea K. Borsodi ${ }^{1, C}$
}

\section{Abstract}

The Molnár János Cave is part of the northern discharge area of the Buda Thermal Karst System, and is the largest active thermal water cave in the capital of Hungary. To compare the prokaryotic communities, reddish-brown cave wall biofilm, black biogeochemical layers, and thermal water samples from the phreatic mixing zone of the cave were subjected to three investigative approaches, scanning electron microscopy, cultivation, and molecular cloning. According to the SEM images, multilayer network structures were observed in the biofilm formed by iron-accumulating filamentous bacteria and mineral crystals. Cultivated strains belonging to Aeromonadaceae and Enterobacteriaceae were characteristic from both water and subaqueous biofilm samples. The most abundant molecular clones were representatives of the phylum Chloroflexi in the reddish-brown biofilm, the class Gammaproteobacteria in the black biogeochemical layer, and Thiobacillus (Betaproteobacteria) in the thermal water samples. The reddish-brown biofilm and black biogeochemical layer's bacterial communities proved to be somewhat more diverse than that of the thermal water. The archaeal 16S rRNA gene clone libraries were dominated by thermophilic ammonia-oxidizer Nitrosopumilus and Nitrososphaera phylotypes in all three habitats. Considering the metabolic characteristics of known species related to the detected clones, it can be assumed that these communities may participate in the local sulfur and nitrogen cycles and may contribute to microbial mediated sulfuric acid speleogenesis.

\section{Introduction}

Under the residential area of Budapest, the capital of Hungary, extensive hypogenic cave systems can be found (Leél-Össy, 1995). They are part of the Buda Thermal Karst System at the northeastern margin of the Transdanubian Central Range (Fig. 1). In addition, they are located on the border of confined and unconfined carbonate aquifers that serve as the discharge zone of thermal water with different origins and temperatures (Mádl-Szönyi and Tóth, 2015). In the system, a southern (Gellért Hill) and a northern subsystem (Rózsadomb) have been separated in terms of the flow systems and types of discharged water. Furthermore, major differences can also be observed in the cave-formation processes (Eröss et al., 2012).

Molnár János Cave belongs to the northern (Rózsadomb) discharge area (Fig. 1), and it is the largest active thermal water cave in Europe (Goldscheider et al., 2010). Discharges of lukewarm $\left(20-35^{\circ} \mathrm{C}\right)$ and warm to hot $\left(40-65^{\circ} \mathrm{C}\right)$ springs are characteristic for this area, and corrosion proved to be the dominant cave forming process (Erőss et al., 2012). The lukewarm springs tend to have lower than $1000 \mathrm{mg} \mathrm{L}^{-1}$ total dissolved solids, while the hot waters contain more than $1200 \mathrm{mg} \mathrm{L}^{-1}$ (Papp, 1942). Bodor et al. (2015) proved that in the Rózsadomb area infiltration from precipitation does not affect the physical and chemical parameters of the discharged waters. First Eröss et al. (2008) published the characteristic chemical data of the cave's spring water $\left(\mathrm{pH}: 6.94 ; \mathrm{T}: 21.7^{\circ} \mathrm{C}\right.$; EC: $\left.932 \mu \mathrm{S} \mathrm{cm}^{-1}\right)$, and later Bodor et al. (2014) found that the temporal variability of the parameters of the spring cave water was negligible.

The chemical characteristics of such hypogenic cave waters are influenced by the type of host rock and the composition of the released gases (Kumaresan et al., 2014). In hypogenic cave systems, microbes can be found in different mineral deposits, streams, snottites, or on cave walls and corrosion residues. Based on the 16S rRNA gene-sequence analysis, members of the phylum Proteobacteria are frequently the most abundant in these habitats. Sulfur-oxidizing bacteria belonging to the classes of Beta-, Gamma- and Epsilonproteobacteria can play an important role in sulfuric acid speleogenesis (Engel, 2011).

In the speleogenesis of Molnár János Cave, microbiologically enforced corrosion was also assumed (Erőss, 2010; Borsodi et al., 2012). In a preliminary study, Firmicutes-related aerobic and anaerobic bacteria, probably participating in local iron and sulfur transformations, were found to be predominant besides Proteobacteria in the iron-rich reddishbrown biofilm formed on the cave wall of the cave (Borsodi et al., 2012).

In the Molnár János Cave, prokaryotes inhabit different habitats, such as the cave walls, where reddish-brown subaqueous biofilm developed, and the black biogeochemical layer can be observed at distinct places on the cave walls under phreatic conditions and in the cavities of the cave, which is almost completely filled with thermal water. As the

\footnotetext{
${ }^{1}$ Department of Microbiology, ELTE Eötvös Loránd University, Pázmány P. sétány 1/C, 1117 Budapest, Hungary

${ }^{2}$ Department of Physical and Applied Geology, ELTE Eötvös Loránd University, Pázmány P. sétány 1/C, 1117 Budapest, Hungary

c Corresponding Author: borsodi.andrea@ttk.elte.hu
} 
Figure 1. The location of Buda Thermal Karst and Rózsadomb in the Transdanubian Range, Hungary.

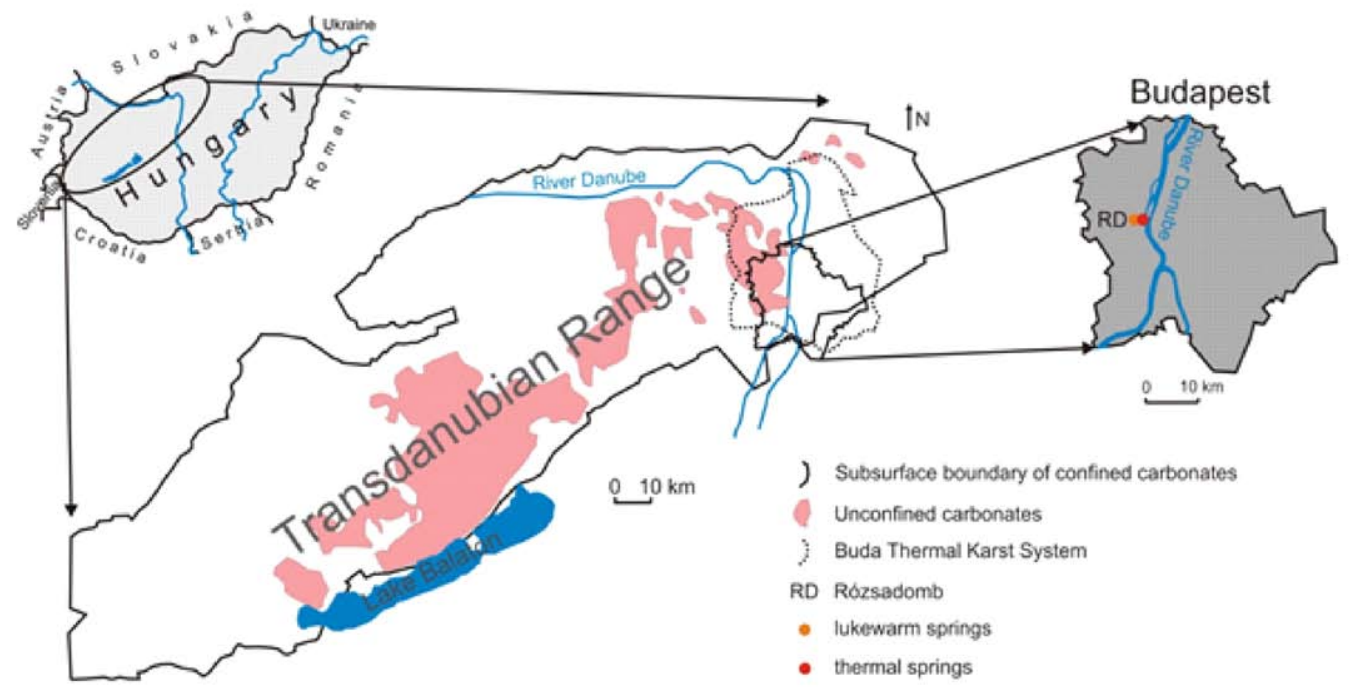

cave is located under a heavily populated area of the capital of Hungary, anthropogenic effects may also have an influence on the composition of the cave microbiota.

The aim of the present research was to gain information about the structure of the prokaryotic communities inhabiting the thermal water, the subaqueous biofilm, and black biogeochemical layers found in the Molnár János Cave mixing zone. To get a more detailed picture about the morphological and genetic diversity of bacterial and archaeal communities, SEM, cultivation, and molecular cloning methods were applied.

\section{Materials and Methods}

\section{Cave Description and Sampling}

The caves of the Rózsadomb are located in the northern part of the Buda Thermal Karst System (Fig. 1). Chambers can be found mostly at the boundary of the Szépvölgy Limestone and the Buda Marl, and the most frequent minerals are calcite $\left(\mathrm{CaCO}_{3}\right)$ and gypsum $\left(\mathrm{CaSO}_{4} \cdot 2 \mathrm{H}_{2} \mathrm{O}\right)$ (Leél-Össy, 1995). Currently, the Molnár János Cave is nearly $6 \mathrm{~km}$ in length, and the explored maximum depth of the cave is 100 meters under the Rózsadomb (Eröss, 2010). The host rock of the cave is marl, sometimes with considerable (up to 80\%) carbonate content. Considering the increasing number of cave divers that regularly visit the Molnár János Cave, the direct human impact on the cave ecology cannot be negligible. The temperature of the cave's water is $23-26^{\circ} \mathrm{C}$ near the surface, and $\sim 19^{\circ} \mathrm{C}$ at $25-35 \mathrm{~m}$ depth in the cave due to the mixing of thermal and lukewarm components (Erőss et al., 2008).

Samples for the microbiological examinations were collected from the Molnár János Cave in December 2012. The sampling process was conducted in collaboration with divers. Submerged reddish-brown biofilm (MJB) and black biogeochemical layer (MJD) samples were collected with the help of sterile scalpels, while thermal water (MJW) filling the cave was collected using sterile bottles. According to the divers, the black biogeochemical layers are sporadically observed throughout the whole submerged cave system. At the time of sampling, the measured water temperature, $\mathrm{pH}$, and conductivity values were $20.1^{\circ} \mathrm{C}, 6.9$ and $1006 \mu \mathrm{S} \mathrm{cm}^{-1}$, respectively. Relatively high sulfate $\left(121 \mathrm{mg} \mathrm{L}^{-1}\right)$ and sulfide $\left(6.9 \mathrm{mg} \mathrm{L}^{-1}\right)$ concentrations were measured in the cave's water; similar to the values reported by Anda et al. (2015). The total organic carbon and the total nitrogen concentrations of the samples were 1.4 and $1.8 \mathrm{mg} \mathrm{L}^{-1}$. Concentrations of $\mathrm{NH}_{4}^{+}-\mathrm{N}, \mathrm{NO}_{3}^{-}-\mathrm{N}$, and $\mathrm{NO}_{2}^{-}-\mathrm{N}$ were less than $0.01,1.7$, and $0.007 \mathrm{mg} \mathrm{L}^{-1}$, respectively. Other detected physical and chemical parameters are reported by Dobosy et al. (2015).

\section{Scanning Electron Microscopy}

For scanning electron microscopy, mucilaginous reddish-brown biofilm samples were filtered onto $0.2 \mu \mathrm{m}$ polycarbonate filters (Millipore). All subsequent steps were the same as previously described (Anda et al., 2014, 2015).

\section{Cultivation}

For cultivation, we used tenfold serial dilutions from the biofilm and thermal-water samples using sterile water and then plated onto R2A (DSMZ Medium 830) and Sphaerotilus-Leptothrix ferrous sulfate (DSMZ Medium 803) media (www.dsmz.de/?id=441). The R2A medium was chosen because, like cave environments, it also contains relatively small amounts of organic compounds as compared to other media. It provides the possibility for the cultivation of slowgrowing oligotrophic bacteria. The ferrous sulfate medium was chosen for cultivation because results of the previous 
studies indicated that bacterial iron oxidation may play an important role in the speleogenesis of the Buda Thermal Karst System (Borsodi et al., 2012; Anda et al., 2014, 2015). Following a 14-day incubation at $20^{\circ} \mathrm{C}$, discrete bacterial colonies with different morphology were isolated.

\section{Bacterial DNA Extraction and PCR Amplification}

The community DNA was isolated using Ultra Clean Soil Kit (MO Bio Inc., CA, USA) according to the manufacturer's instructions, checked in agarose gel (1\%) stained with ECO Safe Nucleic Acid Staining Solution (Avegene, Taiwan), and visualized by UV excitation. DNA of pure cultures was isolated using G-spin Genomic DNA Extraction Kit (iNtRON Biotechnology, South Korea) according to the manufacturer's instructions. The primers and temperature protocol used for bacterial PCR and the construction of 16S rRNA clone libraries was the same as previously applied by Anda et al. (2015).

\section{Identification of Bacterial Strains and Molecular Clones}

PCR products were grouped according to their Amplified Ribosomal DNA Restriction Analysis pattern produced with enzymes Mspl and BsuRI (Fermentas, Lithuania) as described by Anda et al. (2015). The identification of ARDRA group and sequencing reaction were performed as previously described by Anda et al. (2015). Taxonomic relationships of the sequences were determined using the EzTaxon database (Kim et al., 2012) and Basic Local Alignment and Search Tool (BLAST) program (Altschul et al., 1997).

The 16S rRNA gene sequences (on average 800 to 900 bp long) were submitted to the GenBank under accession numbers LN998831-LN998895 for the MJBB (Molnár János reddish-brown biofilm Bacteria) clones, LN998896LN998926 for the MJDB (Molnár János black biogeochemical layer Bacteria) clones, LN998927-LN998931 for the MJWB (Molnár János thermal water Bacteria) clones, LN998932-LN998939 for the MJBA (Molnár János reddishbrown Archaea) clones, LN998940-LN998947 for the MJDA (Molnár János black biogeochemical layer Archaea) clones, LN998948-LN998960 for the MJWA (Molnár János thermal water Archaea) clones, LN998961-LN998974 for the MJB (Molnár János reddish-brown biofilm) strains, and LN998975-LN998982 for the MJW (Molnár János thermal water) strains.

\section{Results}

\section{Scanning Electron Microscopic Observations}

The SEM analysis (Fig. 2A-F) revealed a multilayer network architecture of microbial biofilm formed by filamentous bacteria and other cells, together with mineral crystals and organic matter matrix. The structurally complex biofilm was ordered in layers (yellow arrows) and interconnected (red arrows) with filamentous bacteria together with EPS (Fig. 2C). Intertwined filamentous bacteria similar to groundwater-fed, iron-rich microbial mats (Schieber and Glamoclija, 2007) and wastewater biofilms (Felföldi et al., 2015) were also observed. On some micrographs, taken with the vCD detector, very small spheroid shaped precipitates (Fig. 2C-D) and filamentous bacteria (Fig. 2F) can be seen much brighter (white) compared to their environment. The brightness means that the precipitates carried particles containing elements of higher atomic number, such as heavy metals. The elements of greater atomic number may indicate iron compounds accumulated by microbes as previously shown by EDX analysis in an electron microscopic study on the iron-rich biofilm of the Rudas-Török spring cave in the Buda Thermal Karst (Borsodi et al., 2012). It is also apparent that some parts of the biofilm were covered by a transparent substance consisting of elements of small atomic number $(\mathrm{C}, \mathrm{H}, \mathrm{O}, \mathrm{N})$ that could be the residue of the biofilm extracellular polymeric substance. The EPS covered surface of filamentous forms is clearly visible in the greater magnification of Figure $2 \mathrm{E}$.

\section{Cultivation-Based Bacterial Diversity}

Altogether 66 bacterial strains were isolated from the biofilm (MJB) and water (MJW) samples using two different media (Table 1). The bacterial strains were identified as representatives of phyla Proteobacteria, Firmicutes, and Actinobacteria based on 16S rRNA analysis. From the ferrous sulfate and R2A media 9 and 8 genera were identified, respectively (Table 1). Among them representatives of the genus Aeromonas were found on medium R2A from the MJB sample. In the case of the MJW sample, representatives of the genera Raoultella, Enterobacter, and Citrobacter (Enterobacteriaceae) were cultivated from both media. Among the bacterial strains, representatives of the genus Brevibacillus (Firmicutes) and genera Janibacter and Micrococcus (Actinobacteria) were also cultivated from the MJB sample.

\section{Molecular Clones of Bacteria}

The bacterial 16S rRNA gene based clone libraries containing 200 members were created from each of the three samples. Different numbers of phyla were detected per sample: 3 from the water (MJWB), 6 from the black biogeochemical layer (MJDB), and 9 from the reddish-brown biofilm (MJBB). The relatives of the following phyla and classes were found Betaproteobacteria, Gammaproteobacteria, Nitrospirae, Chloroflexi, Firmicutes, Deltaproteobacteria, Ac- 

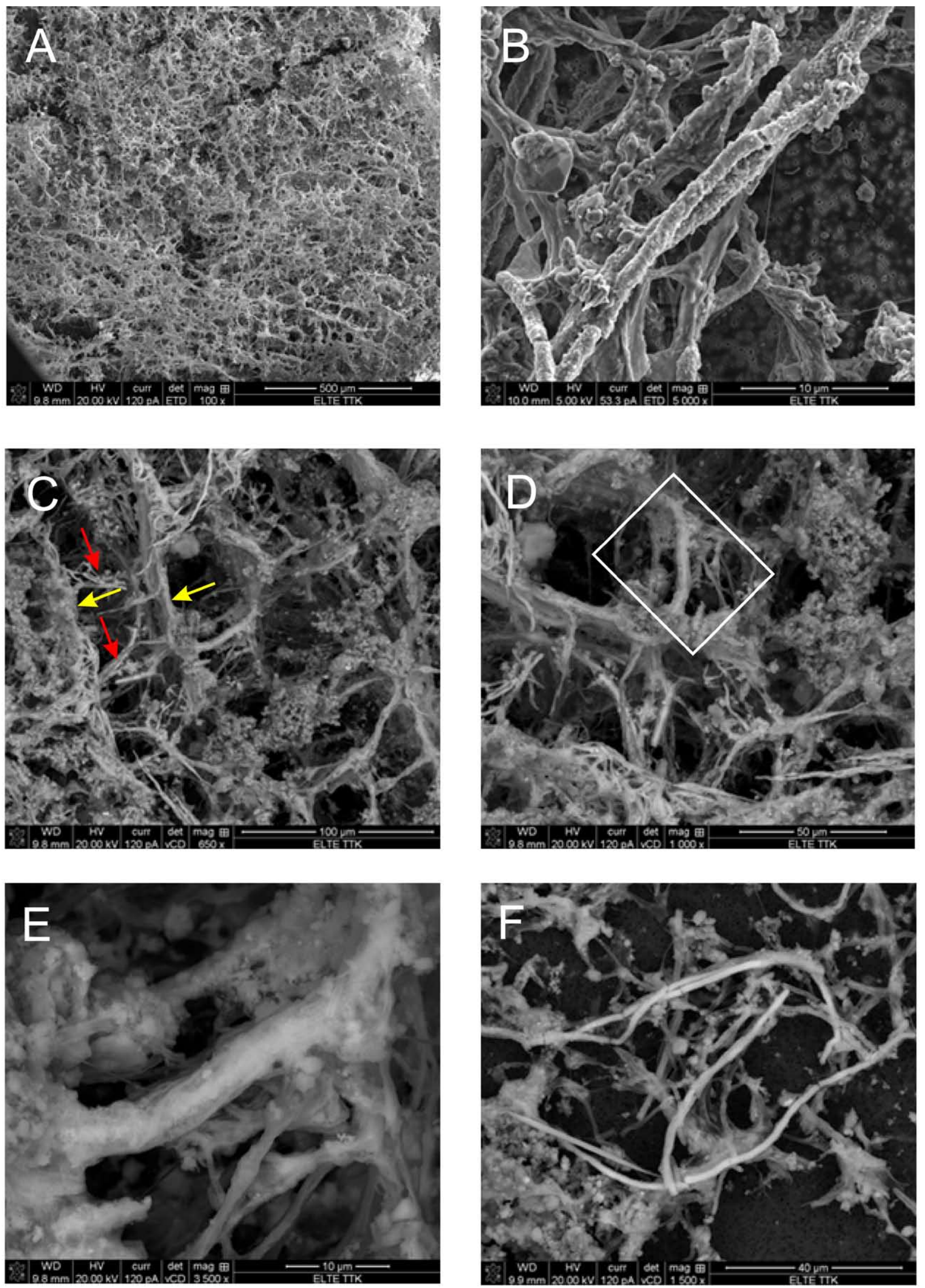

Figure 2. Scanning electron micrographs of naturally grown biofilm samples from Molnár János Cave. Scale bar (A) $500 \mu m$, (C) $100 \mu \mathrm{m}$, (D) $50 \mu \mathrm{m},(F) 40 \mu \mathrm{m}$, (B, E) $10 \mu \mathrm{m}$. 
idobacteria, Alphaproteobacteria, Actinobacteria, Epsilonproteobacteria, Gemmatimonadetes, Spirochaetes, and Verrucomicrobia (Fig. 3). Among them representatives of the class Betaproteobacteria and the phylum Nitrospirae could be identified in all the three samples.

The MJWB clone library was dominated $(96.7 \%)$ by phylotypes belonging to the class Betaproteobacteria. These molecular clones showed the highest sequence similarity (95.42\%) to the genus Thiobacillus. In the MJBB clone library, representatives of the phyla Chloroflexi (33.6\%) were the most abundant. Within this phylum, phylotypes $(12.5 \%)$ related to the order Anaerolineales were identified. In the MJDB clone library, the dominance (29.1\%) of the genus Methylohalomonas-related (Gammaproteobacteria) clones was found. The second most abundant group of the molecular clones showed the highest sequence matching (95.88\% and $95.33 \%)$ with the widespread species of Nitrospira moscoviensis (Ehrich et al., 1995) and Nitrospira calida (Lebedeva et al., 2011).

Figure 3. Taxonomic classification of 16S rRNA gene sequences of the bacterial clone libraries from the Molnár János Cave.

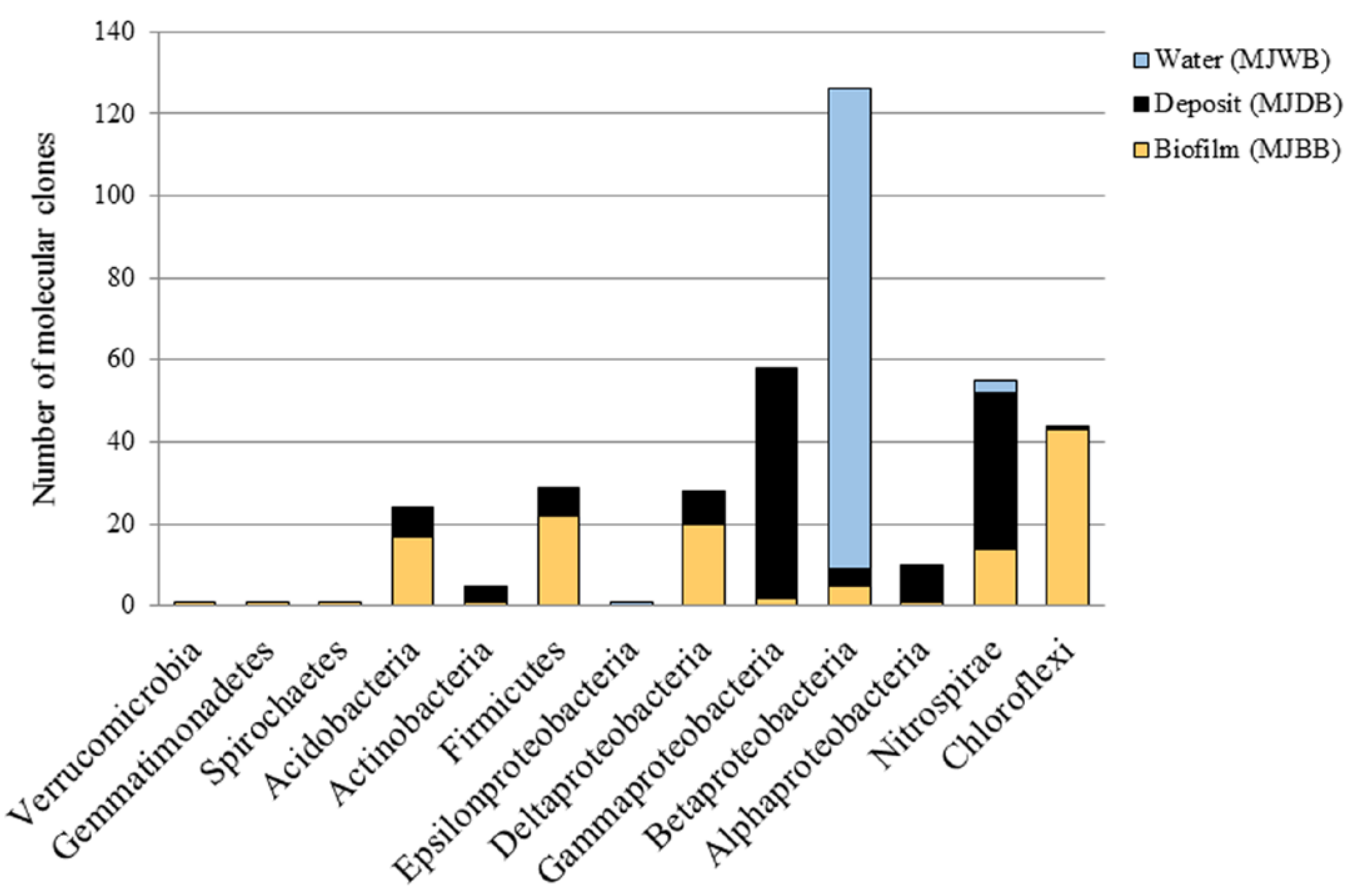

\section{Molecular Clones of Archaea}

Three archaeal 16S rRNA clone libraries were also constructed from the reddish-brown biofilm (MJBA), the black biogeochemical layer (MJDA), and the water (MJWA) of Molnár János Cave. Each clone library contained 100 members. The 16S rRNA gene sequences of the representative clones belonged to the phyla Euryarchaeota and Thaumarchaeota (Fig. 4). In all three libraries, the phylum Thaumarchaeota (MJWA: $68.2 \%$, MJBA: $97.85 \%$, MJDA: 100\%) was the most abundant. Members of the phylum Euryarchaeota were only found in the case of the MJBA (2.15\%) and MJWA (31.8\%) samples. In the MJWA clone library, phylotypes were closely related to the "Candidatus Nitrososphaera gargensis" and Nitrososphaera viennensis (with $97.36 \%$ and $97.79 \%$ sequence similarities).

In both clone libraries (MJBA, MJDA) from the surface associated samples, representatives of "Candidatus Nitrososphaera gargensis" (MJBA: 35.48\%, MJDA: 16.7\%), Nitrososphaera viennensis (Stieglmeier et al., 2014) (MJBA: 32.3\%, MJDA: 46.6\%), and "Candidatus Nitrosoarchaeum limnia" (MJBA: 29.03\%, MJDA: 23.3\%) were the most abundant.

\section{Discussion}

The Molnár János Cave, belonging to the Rózsadomb discharge area of the Buda Thermal Karst System, is the largest active thermal water system in Europe where microorganisms can be studied. This study looked at three ecological niches within the cave system: thermal water, subaqueous black biogeochemical layer, and reddish-brown biofilm on the subaqueous cave wall. The Proteobacteria was one of the most abundant bacterial phylum in the studied habitats of the cave, as revealed both by cultivation and molecular cloning. However, the dominant members of the classes Gamma- and Betaproteobacteria showed different distributions according to the sample types and methods used for examinations. The presence of the genus Aeromonas was identified among the strains isolated from the reddish-brown biofilm (Table 1). This biofilm growth pattern differs from previous studies that found Aeromonas species to be common members of freshwater planktonic communities (Langó et al., 2002). The occurrence of these indicator organisms in the 
Figure 4. Taxonomic classification of 16S rRNA gene sequences of the archaeal clone libraries from the Molnár János Cave.

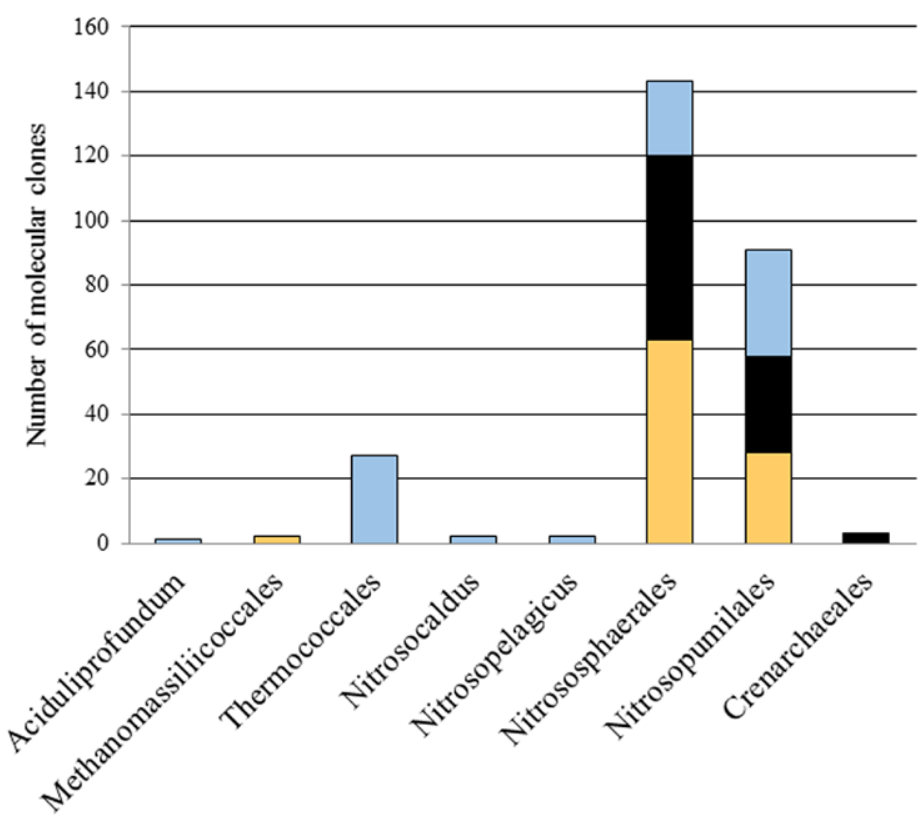

$\square$ Water (MJWA)

-Deposit (MJDA)

$\square$ Biofilm (MJBA)

Table 1. Cultivated strains from the thermal water and reddish-biofilm samples inhabiting the Molnár János Cave. Notes: R: R2A medium, I: ferrous-sulfate medium, B: reddish-brown biofilm sample, W: thermal water sample.

\begin{tabular}{|c|c|c|c|c|c|}
\hline \multirow[t]{2}{*}{ Taxonomic Identification } & \multirow{2}{*}{$\begin{array}{l}\text { Representative Strain } \\
\text { (Accession Number) }\end{array}$} & \multirow[t]{2}{*}{ Similarity \% (bp) } & \multirow{2}{*}{$\begin{array}{l}\text { Origin of the } \\
\text { Sample }\end{array}$} & \multicolumn{2}{|c|}{ Media } \\
\hline & & & & $\mathrm{R}$ & I \\
\hline \multicolumn{6}{|l|}{ Alphaproteobacteria } \\
\hline Brevundimonas bullata (D12785) & MJW-S108 (LN998978) & $100 \%(0 / 1090)$ & W & + & \\
\hline Caulobacter henricii (AJ227758) & MJB-S139 (LN998974) & $98.50 \%(10 / 667)$ & B & & + \\
\hline Paracoccus yeei (AY014173) & MJW-S104 (LN998975) & $99.78 \%(2 / 914)$ & W & + & \\
\hline \multicolumn{6}{|l|}{ Betaproteobacteria } \\
\hline Xylophilus ampelinus (AF078758) & MJB-S116 (LN998968) & $97.78 \%(21 / 944)$ & B & & + \\
\hline Variovorax boronicumulans (AB300597) & MJB-S128 (LN998972) & $98.83 \%(10 / 853)$ & B & & + \\
\hline Vogesella alkaliphila (HE819389) & MJB-S123 (LN998970) & $98.64 \%(13 / 955)$ & B & & + \\
\hline \multicolumn{6}{|l|}{ Gammaproteobacteria } \\
\hline \multirow[t]{3}{*}{ Aeromonas veronii (X60414) } & MJB-S102 (LN998961) & $99.71 \%(3 / 1044)$ & B & + & \\
\hline & MJB-S104 (LN998962) & $100 \%(0 / 1010)$ & B & + & \\
\hline & MJB-S108 (LN998965) & $100 \%(0 / 966)$ & B & + & \\
\hline Citrobacter freundii (ANAV01000046) & MJB-S137 (LN998973) & $99.80 \%(2 / 983)$ & B & & + \\
\hline \multirow[t]{2}{*}{ Citrobacter youngae (AJ564736) } & MJW-S106 (LN998976) & $99.78 \%(2 / 915)$ & W & + & \\
\hline & MJW-S123 (LN998981) & $99.79 \%(2 / 931)$ & W & & + \\
\hline \multirow[t]{2}{*}{ Enterobacter ludwigii (AJ853891) } & MJW-S107 (LN998977) & $98.76 \%(10 / 806)$ & W & + & \\
\hline & MJW-S122 (LN998980) & $99.24 \%(8 / 1047)$ & W & & + \\
\hline Pantoea dispersa (DQ504305) & MJB-S107 (LN998964) & $98.67 \%(14 / 1054)$ & B & + & \\
\hline \multirow[t]{2}{*}{ Raoultella terrigena (Y17658) } & MJW-S109 (LN998979) & $99.39 \%(5 / 822)$ & W & + & \\
\hline & MJW-S126 (LN998982) & $99.43 \%(6 / 1050)$ & W & & + \\
\hline \multicolumn{6}{|l|}{ Firmicutes } \\
\hline Brevibacillus fluminis (EU375457) & MJB-S119 (LN998969) & $97.96 \%(20 / 981)$ & B & & + \\
\hline Brevibacillus ginsengisoli (AB245376) & MJB-S125 (LN998971) & $97.41 \%(27 / 1042)$ & B & & + \\
\hline \multicolumn{6}{|l|}{ Actinobacteria } \\
\hline Janibacter terrae (AF176948) & MJB-S105 (LN998963) & $99.90 \%(1 / 992)$ & B & + & \\
\hline Micrococcus yunnanensis (FJ214355) & MJB-S113 (LN998966) & $99.81 \%(2 / 1046)$ & B & & + \\
\hline & MJB-S114 (LN998967) & $99.90 \%(1 / 991)$ & B & & + \\
\hline
\end{tabular}


cave water possibly suggests human influence, because their growth is facilitated by organic matter input (Araujo et al., 1989). The water of Molnár János Cave is currently thought to be supplied by karst and basinal fluids according to the numerical flow simulation (Mádl-Szőnyi and Tóth, 2015). Nevertheless, in the caves of Buda, the role of sewer leakage cannot be excluded under the residential area (Virág et al., 2009; Bergmann et al., 2011). In this study, representatives of Enterobacteriaceae (Gammaproteobacteria) were identified in the water from the cave, but presence of fecal coliforms was not verified by molecular or culturing methods, indicating that the infiltration from the surface was negligible. Members of the family Enterobacteriaceae with facultative anaerobic, Gram-negative, non-spore-forming, rod-shaped cells have been found in the caves of the Slovak Karst, too. In that case correlation was found between biological pollution and agricultural activity (Seman et al., 2015).

The similarity values of the partial $16 \mathrm{~S}$ rRNA gene sequences of molecular clones to previously described species were below the (>97\%) identification level (Stackebrandt and Goebel, 1994) in almost all cases. The sequence analysis of the representative molecular clones (selected by ARDRA grouping) resulted in the closest matches (with $87 \%$ to $99 \%$ sequence similarities) mainly to uncultured clone sequences from different environmental sources such as caves, thermal springs, soils, and sediments (Hansel et al., 2008; Lin et al., 2012; Ivanova et al., 2013).

In the water clone library (MJWB), a high proportion (94.2\%) of molecular clones was found to be related to Thiobacillus species (Betaproteobacteria). The genus Thiobacillus consists of chemolithotrophic sulfur-oxidizing bacteria with diverse metabolisms that are a common constituent of sulfuric freshwater, marine, and subsurface habitats (Kelly and Wood, 2000). The bacterial sulfur metabolism is significant in different caves, so sulfur-oxidizing bacteria have a crucial role in sulfuric acid speleogenesis. During their metabolism, as a by-product of sulfide oxidation, the bacteria produce sulfuric acid that dissolves carbonates (Engel, 2011; Kumaresan et al., 2014). In the water of Molnár János Cave, relatively high amounts of sulfide were measured, similar to that of the thermal water of Városliget-II well, another member of the Buda Thermal Karst System. The phylotypes related to the species of Thiobacillus aquesulis were the most abundant according to the 16S rRNA gene sequences (Anda et al., 2015). By comparing these results against the Thiobacillus-related representatives from these habitats (MJWB-C7 and VLWB-C7), a 99\% sequence matching was found, demonstrating the dominance of the same phylotype in both Buda Thermal Karst System communities.

In the black biogeochemical layer clone library (MJDB), the majority of the clones (29.1\%) was associated with the genus Methylohalomonas (Gammaproteobacteria), which is distantly related $(90.18 \%$ sequence similarity) to the moderately halophilic and obligate methylotrophic M. lacus. Previously Chen et al. (2009) described the dominance of methylotrophic organisms from the Movile Cave, Romania. The facultative methylotrophic bacterium Methylobacterium radiotolerans has also detected from the thermal water of the T6 karst well of Harkány Spring, located in southwestern Hungary. It indicates that biological metabolism of methane may also be important in these karst cave environments (Miseta et al., 2012).

The reddish-brown biofilm clone library (MJBB) was dominated by bacteria belonging to the phylum Chloroflexi. The filamentous bacteria were observed in the SEM images. Among them, the order Anaerolineales was identified in the highest proportion (37.2\% of the phylum Chloroflexi). Members of the phylum Chloroflexi, such as Bellilinea caldifistulae (Yamada et al., 2007), are also prevalent in the biofilm developed on the inner surface of an outflow pipeline of the Városliget-II thermal well (Anda et al., 2015). Chloroflexus spp. were also identified from hypogenic caves, such as the Lower Kane Cave in Wyoming, Frasassi Cave System in Italy, and Cueva de Villa Luz in Mexico (Engel, 2007). In addition, several bacterial clones from the reddish-brown biofilm library showed high sequence matching (81.03-94.07\%) with different thermophilic sulfate reducing species of the genera Desulfuromonas, Desulfomonile (Deltaproteobacteria), Thermanaeromonas (Firmicutes) and Thermodesulfovibrio (Nitrospirae). Sulfur and sulfate reducing Deltaproteobacteria (including the genus Desulfuromonas) have also detected in the biofilm of the Rudas-Török spring cave and Diana-Hygieia thermal spring, in the southern area of the Buda Thermal Karst System (Borsodi et al., 2012; Anda et al., 2014). During a previous study of the reddish-brown biofilm of Molnár János Cave, the majority of the molecular clones were related to thermophilic aerobic and anaerobic bacteria belonging to phylum Firmicutes (Borsodi et al., 2012). The members of this phylum (representatives of orders Clostridiales and Thermoanaerobacterales) were confirmed to be significant in this clone library, as well.

Studying the role of the ammonia and nitrite-oxidizing bacteria and ammonia-oxidizing archaea in cave environments and thermal springs has become a research hotspot recently (Chen et al., 2009; Tetu et al., 2013; Ortiz et al., 2014). Thermophilic nitrite-oxidizing bacteria (genus Nitrospira) often appear in different spring caves (Marks et al., 2012; Anda et al., 2014). In the black biogeochemical layer of Molnár János Cave, the phylum Nitrospirae was the second most abundant group. The molecular clones showed the highest sequence matching (95.88\%) with the species Nitrospira moscoviensis described from a corroded iron pipe (Ehrich et al., 1995). Previously, the phylum Nitrospirae was also found to be dominant in the water and biofilm of another thermal spring of the Buda Thermal Karst System (Anda et al., 2014). Besides the nitrite-oxidizing bacteria, ammonia-oxidizing archaea also play an important role in the nitrogen cycle of different karstic environments (Ortiz et al., 2014; Stahl and de la Torre, 2012; Bartossek et al., 
2012). Among the ammonia oxidizing prokaryotes, chemolithoautotrophic ammonia-oxidizing archaea are dominant, and these microorganisms can be found in a wider range of habitats, such as hot springs and acidic soils, than ammonia-oxidizing bacteria (Stahl and de la Torre, 2012). The functional and taxonomic composition of the speleothem metagenome of Kartchner Caverns (Arizona, USA) and the Nullarbor Plain aquatic Weebubbie Cave, Australia, shows a dominance of ammonia-oxidizing archaea belonging to the phylum Thaumarchaeota. The Thaumarchaeota are recognized to be dominant players in global nitrification (Stahl and de la Torre, 2012). In the case of the Kartchner Caverns, Thaumarchaeota reads were classified as Nitrosopumilus maritimus $(13 \%)$ and Nitrososphaera gargensis $(4.7 \%)$. The former is an ammonia-oxidizing marine archaeon (member of group I. 1a), while the latter can often be found in terrestrial environments (Ortiz et al., 2014; Tetu et al., 2013). Representatives of Nitrososphaera gargensis were also found in high proportion in the Molnár János Cave (brown biofilm 33 clones, black biogeochemical layer, and water 15 clones) samples.

\section{Conclusions}

Prokaryotic communities participating mainly in the sulfur cycle of Molnár János Cave located in the Buda Thermal Karst System showed habitat dependent distribution. The reddish-brown biofilm formed on the subaqueous cave wall was dominated by anaerobic bacteria belonging to the filamentous Chloroflexi and sulfate reducing Deltaproteobacteria, while aerobic sulfur-oxidizing Thiobacillus (Betaproteobacteria) were the most abundant in the water of the cave. In addition, Aeromonas and the family Enterobacteriaceae were also detected here, indicating human impact. In the black biogeochemical layer, the majority of the phylotypes were associated with methylotrophic species. On the contrary, phylotypes related to ammonia-oxidizing archaea (Nitrosopumilus and Nitrososphaera) and nitrite-oxidizing bacteria (Nitrospirae) were found to be abundant in all three habitats. Therefore, it can be assumed that nitrogen biotransformation may also be an important microbial process beside the sulfuric acid speleogenesis in the studied hypogenic cave.

\section{Acknowledgements}

This research was supported by the Hungarian Scientific Research Fund (OTKA) Grant NK101356. The authors are grateful to József Spanyol for his assistance in collecting the samples. The technical support of Petra Bodor is also gratefully acknowledged.

\section{References}

Altschul, S.F., Madden, T.L., Schaeffer, A.A., Zhang, Jinghui, Zhang, Zheng, Miller, W., and Lipman, D.J., 1997, Gapped BLAST and PSI-BLAST: a new generation of protein database search programs: Nucleic Acids Research, v. 25, p. 3389-3402.

Anda, D., Büki, G., Krett, G., Makk, J., Márialigeti, K., Erőss, A., Mádl-Szőnyi, J., and Borsodi, A.K., 2014, Diversity and morphological structure of bacterial communities inhabiting the Diana-Hygieia thermal spring (Budapest, Hungary): Acta Microbiologica et Immunologica Hungarica, v. 61, p. 329-346. https://doi.org/10.1556/AMicr.61.2014.3.7.

Anda, D., Makk, J., Krett, G., Jurecska, L., Márialigeti, K., Mádl-Szőnyi, J., and Borsodi, A.K., 2015, Thermophilic prokaryotic communities inhabiting the biofilm and well water of a thermal karst system located in Budapest (Hungary): Extremophiles, v. 19, p. 787-797. https://doi. org/10.1007/s00792-015-0754-1.

Araujo, R.M., Arribas, R.M., Lucena, F., and Pares, R., 1989, Relation between Aeromonas and fecal coliforms in fresh waters: Journal of Applied Bacteriology, v. 67, no. 2, p. 213-217. 1https://doi.org/0.1111/j.1365-2672.1989.tb03398.x.

Bartossek, R., Spang, A., Weidler, G., Lanzen, A., and Schleper, C., 2012, Metagenomic analysis of ammonia-oxidizing Archaea affiliated with soil group: Frontiers in Microbiology, v. 3, p. 208. https://doi.org/10.3389/fmicb.2012.00208.

Bergmann, Cs., Leél-Össy, Sz., Fehér, K., and Fórizs, I., 2011, Vízvizsgálatok a Molnár János-barlangban (Water examinations in Molnár János Cave): Karsztfejlődés, v. 16, p. 223-245.

Bodor, P., Erőss, A., Mádl-Szőnyi, J., and Czuppon, Gy., 2014, A Duna és a felszín alatti vizek kapcsolata a rózsadombi megcsapolódási területen (Interaction between the groundwater and the Danube at the Rózsadomb discharge area): Karsztfejlődés, v. 19, p. 63-75.

Bodor, P., Erőss, A., Mádl-Szőnyi, J., and Kovács, J., 2015, A csapadék hatása a rózsadombi források utánpótlódási és megcsapolódási területén (The effect of precipitation at the recharge and discharge area of the springs of Rózsadomb, Buda Thermal Karst, Hungary): Földtani Közlöny, v. 154, no. 4, p. 385-396.

Borsodi, A.K., Knáb, M., Krett, G., Makk, J., Márialigeti, K., Erőss, A., and Mádl-Szőnyi, J., 2012, Biofilm bacterial communities inhabiting the cave walls of the Buda Thermal Karst System, Hungary: Geomicrobiology Journal, v. 29, no. 7, p. 611-627. http://dx.doi.org/10.1080/01490451 .2011.602801.

Chen, Yin, Wu, Liqin., Boden, R., Hillebrand, A., Kumaresan, D., Moussard, H., Baciu, M., Lu, Yahai, and Colin Murrell, J., 2009, Life without light: microbial diversity and evidence of sulfur- and ammonium-based chemolithotrophy in Movile Cave: The ISME Journal, v. 3, p. $1093-1104$. https://doi.org/10.1038/ismej.2009.57.

Dobosy, P., Sávoly, Z., Óvári, M., Mádl-Szőnyi, J., and Záray, Gy., 2015, Microchemical characterization of biogeochemical samples collected from the Buda Thermal Karst System, Hungary: Microchemical Journal, v. 124, p. 116-120. http://dx.doi.org/10.1016/j.microc.2015.08.004.

Ehrich, S., Behrens, D., Lebedeva, E., Ludwig, W., and Bock, E., 1995, A new obligately chemolithoautotrophic, nitrite-oxidizing bacterium, Nitrospira moscoviensis sp. nov. and its phylogenetic relationship: Archives of Microbiology, v. 164, no. 1, p. 16-23. https://doi.org/10.1007/ BF02568729.

Engel, A.S., 2007, Observations on the biodiversity of sulfidic karst habitats: Journal of Cave and Karst Studies, v. 69, p. $187-206$.

Engel, A.S., 2011, Karst ecosystems, in Reitner, J., and Thiel, V., editors, Encyclopedia of Geobiology: Berlin, Springer, Encyclopedia of Earth Sciences Series (EESS, formerly Kluwer Edition), Berlin. p. 521-531. https://doi.org/10.1007/978-1-4020-9212-1.

Erőss, A., 2010, Characterization of fluids and evaluation of their effects on karst development at the Rózsadomb and Gellért Hill, Buda Thermal Karst, Hungary, [PhD thesis], Eötvös Loránd University. 171 p. 
Erőss, A., Mádl-Szőnyi, J., and Csoma, A.É., 2008, Characteristics of discharge at Rose and Gellért Hills, Budapest, Hungary: Central European Geology, v. 51, p. 267-281. https://doi.org/10.1556/CEuGeol.51.2008.3.8.

Erőss, A., Mádl-Szőnyi, J., Surbeck, H., Horváth, Á., Goldscheider, N., and Csoma, A.É., 2012, Radionuclides as natural tracers for the characterization of fluids in regional discharge areas, Buda Thermal Karst, Hungary: Journal of Hydrology, v. 426-427, p. 124-137. http://dx.doi. org/10.1016/j.jhydrol.2012.01.031.

Felföldi, T., Jurecska, L., Vajna, B., Barkács, K., Makk, J., Cebe, G., Szabó, A., Záray, Gy., and Márialigeti, K., 2015, Texture and type of polymer fiber carrier determine bacterial colonization and biofilm properties in wastewater treatment: Chemical Engineering Journal, v. 264, p. 824-834. http://dx.doi.org/10.1016/j.cej.2014.12.008.

Goldscheider, N., Mádl-Szőnyi, J., Erőss, A., and Schill, E., 2010, Review: thermal water resources in carbonate rock aquifers: Hydrogeology Journal, v. 18, p. 1303-1318. https://doi.org/10.1007/s10040-010-0611-3.

Hansel, C.M., Fendorf, S., Jardine, P. M., Francis, C.A., 2008, Changes in bacterial and archaeal community structure and functional diversity along a geochemically variable soil profile: Applied and Environmental Microbiology, v. 74, no. 5, p. 1620-1633. https://doi.org/10.1128/ AEM.01787-07.

Ivanova, V., Tomova, I., Kamburov, A., Tomova, A., Vasileva-Tonkova, E., Kambourova, M., 2013, High phylogenetic diversity of bacteria in the area of prehistoric paintings in Magura cave, Bulgaria: Journal of Cave and Karst Studies, v. 75, no. 3, p. 218-228. http://dx.doi.org/10.4311/ 2012MB0279.

Kelly, D.P., and Wood, A.P., 2000, Reclassification of some species of Thiobacillus to the newly designated genera Acidithiobacillus gen. nov., Halothiobacillus gen. nov. and Thermithiobacillus gen. nov.: International Journal of Systematic and Evolutionary Microbiology, v. 50, p. 511516.

Kim, Ok-Sun, Cho, Yong-Joon, Lee, Kihyun, Yoon, Seok-Hwan, Kim, Mincheol, Na, Hyunsoo, Park, Sang-Cheol, Jeon, Yoon Seong, Lee, Jae-Hak, Yi, Hana, Won, Sungho, and Chun, Jongsik, 2012, Introducing EzTaxon-e: a prokaryotic 16S rRNA gene sequence database with phylotypes that represent uncultured species: International Journal of Systematic and Evolutionary Microbiology, v. 62, p. 716-721. https://doi. org/10.1099/ijs.0.038075-0.

Kumaresen, D., Wischer, D., Stephenson, J., Hillebrand-Voiculescu, A., and Murrel, J.C. 2014, Microbiology of Movile Cave - a chemolithoautotrophic ecosystem: Geomicrobiology Journal, v. 31, p. 186-193. http://dx.doi.org/10.1080/01490451.2013.839764.

Langó, Zs., Borsodi, A.K., and Micsinai, A., 2002, Comparative studies on Aeromonas strains isolated from lakes Balaton (Hungary) and Fertő/ Neusiedlersee (Hungary): Acta Microbiologica et Immunologica Hungarica, v. 49, p. 37-45. http://dx.doi.org/10.1556/AMicr.49.2002.1.4.

Lebedeva, E.V., Off, S., Zumbrägel, S., Kruse, M., Shagzhina, A., Lücker, S., Maixner, F., Lipski, A., Daims, H., and Spieck, E., 2011, Isolation and characterization of a moderately thermophilic nitrite-oxidizing bacterium from a geothermal spring: FEMS Microbiology Ecology, v. 75, no. 2, p. 195-204. https://doi.org/10.1111/j.1574-6941.2010.01006.x.

Leél-Össy, Sz., 1995, A Rózsadomb és környékének különleges barlangjai (Particular caves of the Rózsadomb Area): Földtani Közlöny, v. 125, no. 3-4, p. 363-432.

Lin, Xueju, Kennedy, D., Fredrickson, J., Bjornstad, B., and Konopka, A., 2012, Vertical stratification of subsurface microbial community composition across geological formations at the Hanford Site: Environmental Microbiology, v. 14, no. 2, p. 414-425. https://doi.org/10.1111/j.14622920.2011.02659.x.

Mádl-Szőnyi, J., and Tóth, Á., 2015, Basin-scale conceptual groundwater flow model for an unconfined and confined thick carbonate region: Hydrogeology Journal, v. 23, no. 7, p. 1359-1380. https://doi.org/10.1007/s10040-015-1274-X.

Marks, C.R., Stevenson, B.S., Rudd, S., and Lawson, P.A., 2012, Nitrospira-dominated biofilm within a thermal artesian spring: a case for nitrification-driven primary production in a geothermal setting: Geobiology, v. 10, no. 5, p. 457-456. https://doi.org/10.1111/j.1472-4669.2012.00335. $\mathrm{x}$.

Miseta, R., Palatinszky, M., Makk, J., Márialigeti, K., and Borsodi, A.K., 2012, Phylogenetic diversity of bacterial communities associated with sulfurous karstic well waters of a Hungarian spa: Geomicrobiology Journal, v. 29, p. 101-113. http://dx.doi.org/10.1080/01490451.2011.558563.

Ortiz, M., Legatzki, A., Neilson, J.W., Fryslie, B., Nelson, W.M., Wing, R.A., Soderlund, C.A., Pryor, B.M., and Maier, R.M., 2014, Making a living while starving in the dark: metagenomic insights into the energy dynamics of a carbonate cave: The ISME Journal, v. 8, no. 2, p. $478-491$. https://doi.org/10.1038/ismej.2013.159.

Papp, F., 1942, Budapest meleg gyógyforrásai (Thermal medicinal springs of Budapest: Budapest, A Budapesti Központi Gyógy- és Üdülöhelyi Bizottság Rheuma és Fürdőkutató Intézet kiadványa (Budapest Central Spa and Resort and Spa Commission Rheumatism Research Institute), $252 \mathrm{p}$.

Schieber, J., and Glamoclija, M., 2007, Microbial mats built by iron bacteria: a modern example from southern Indiana, in Schieber, J., Bose, P.K. Eriksson, P.G., Banerjee, S., Sarkar, S., Altermann, W., and Catuneau, O., eds., Atlas of Microbial Features Preserved within the Clastic Rock Record: Elsevier, Atlases in Geoscience 2, p. 233-244.

Seman, M., Gaálová, B., Cíchová, M., Prokšová, M., Haviarová, D., and Flaková, R., 2015, The occurrence of coliform bacteria in the cave waters of Slovak Karst, Slovakia: Folia Microbiologica, v. 60, no. 269-278. https://doi.org/10.1007/s12223-014-0362-y.

Stackebrandt, E., and Goebel, B.M., 1994, Taxonomic note: A place for DNA-DNA reassociation and 16S rRNA sequence analysis in the present species definition in bacteriology: International Journal of Systematic Bacteriology, v. 44, p. 846-849. https://doi.org/10.1099/00207713-44-4846.

Stahl, D.A., and de la Torre, J.R., 2012, Physiology and diversity of ammonia-oxidizing archaea: Annual Review of Microbiology, v. 66, p. 83-101. https://doi.org/10.1146/annurev-micro-092611-150128.

Stieglmeier, M., Klingl, A., Alves, R.J., Rittmann, S.K., Melcher, M., Leisch, N., and Schleper, C., 2014, Nitrososphaera viennensis gen. nov., sp. nov., an aerobic and mesophilic, ammonia-oxidizing archaeon from soil and a member of the archaeal phylum Thaumarchaeota: International Journal of Systematic and Evolutionary Microbiology, v. 64, p. 2738-2752. https://doi.org/10.1099/ijs.0.063172-0.

Tetu, S.G., Breakwell, K., Elbourne, L.D.H., Holmes, A.J., Gillings, M.R., and Paulsen, I.T., 2013, Life in the dark: metagenomic evidence that a microbial slime community is driven by inorganic nitrogen metabolism: The ISME Journal, v. 7, no. 6, p. 1227-1236. https://doi.org/10.1038/ismej.2013.14.

Virág, M., Mádl-Szőnyi, J., and Mindszenty, A., 2009, A Szemlő-hegyi-barlang csepegő vizeinek vizsgálata: természetes és antropogén hatások (Examination of drip waters in the Szemlö-hegy Cave: natural and anthropogenic impacts): Karszt és Barlang, 2009, no. 1-2, p. $19-26$.

Yamada, T., Imachi, H., Ohashi, A., Harada, H., Hanada, S., Kamagata, Y., and Sekiguchi, Y., 2007, Bellilinea caldifistulae gen. nov., sp. nov. and Longilinea arvoryzae gen. nov., sp. nov., strictly anaerobic, filamentous bacteria of the phylum Chloroflexi isolated from methanogenic propionate-degrading consortia: International Journal of Systematic and Evolutionary Microbiology, v. 57, p. 2299-2306. https://doi.org/10.1099/ ijs.0.65098-0. 